University of New Mexico UNM Digital Repository

HSC Education Day

Health Sciences Center Events

9-28-2018

\title{
Comparison of a Flipped Classroom to a Traditional Format in a Critical Care Curriculum
}

Erik Kraai

Shozab Ahmed

Benjamin Deaton

Tyler Shackelford

Michel Boivin

Follow this and additional works at: https://digitalrepository.unm.edu/hsc_ed_day

\section{Recommended Citation}

Kraai, Erik; Shozab Ahmed; Benjamin Deaton; Tyler Shackelford; and Michel Boivin. "Comparison of a Flipped Classroom to a Traditional Format in a Critical Care Curriculum." (2018). https://digitalrepository.unm.edu/hsc_ed_day/25

This Poster is brought to you for free and open access by the Health Sciences Center Events at UNM Digital Repository. It has been accepted for inclusion in HSC Education Day by an authorized administrator of UNM Digital Repository. For more information, please contact disc@unm.edu. 


\section{THE UNIVERSITY of NEW MEXICO}

HOSPITAL

\section{Comparison of a Flipped Classroom to a Traditional Format in a Critical Care Curriculum}

Erik Kraai, Shozab Ahmed, Benjamin Deaton, Tyler Shackelford, Michel Boivin.

University of New Mexico Hospital, Albuquerque, NM

\section{BACKGROUND}

Medical education has seen a paradigm shift away from traditional lecture-based teaching towards learner-centered strategies such as problem-based learning and the flipped classroom. The intensive care unit (ICU) poses unique challenges as a learning environment and teaching is complicated by high clinical demands, duty hour restrictions, and unpredictable schedules. The flipped or inverted classroom utilizes pre-class videos to deliver content to the learner prior to in-class sessions that apply fundamental concepts. The potential benefits of the flipped classroom method include the ability of learners to learn new material at their own pace outside the classroom and to engage in active learning during group activities during class time. However, the flipped classroom is not universally accepted and poses challenges including potentially increased time commitments from instructors, need for familiarity with computerbased teaching methods, and methods to assure learners complete out-of-class work. Furthermore, there is little high-quality evidence that the flipped classroom is superior to traditional methods of teaching. We developed a study to compare the two methods in the delivery of a critical care curriculum.

\section{METHODS}

Study Design: Randomized , 2-group.

Setting: Conducted in the medical ICU (MICU) at the 450-bed UNM Health Sciences Center

Population: Interns and medical students completing a 1-month rotation in the MICU.

Instructional Materials: Twelve flipped-classroom 20-minute videos with 30-minute in-class case reviews compared to 12 traditional 50minute lectures on basic critical care topics.

Randomization process: Each month lectures were randomized with 6

lectures to be given in a flipped format and 6 in a traditional format. Data Collected: Learners took a pre-test at the beginning of their rotation and a post-test at the end. A survey using a 5-point scale was given to learners at the end of the rotation to assess their satisfaction and preferences.

Data Analysis: The results over a 8-month period were compared using a t-test to determine if the flipped method was superior to the traditional method.

\section{STUDY FORMAT}
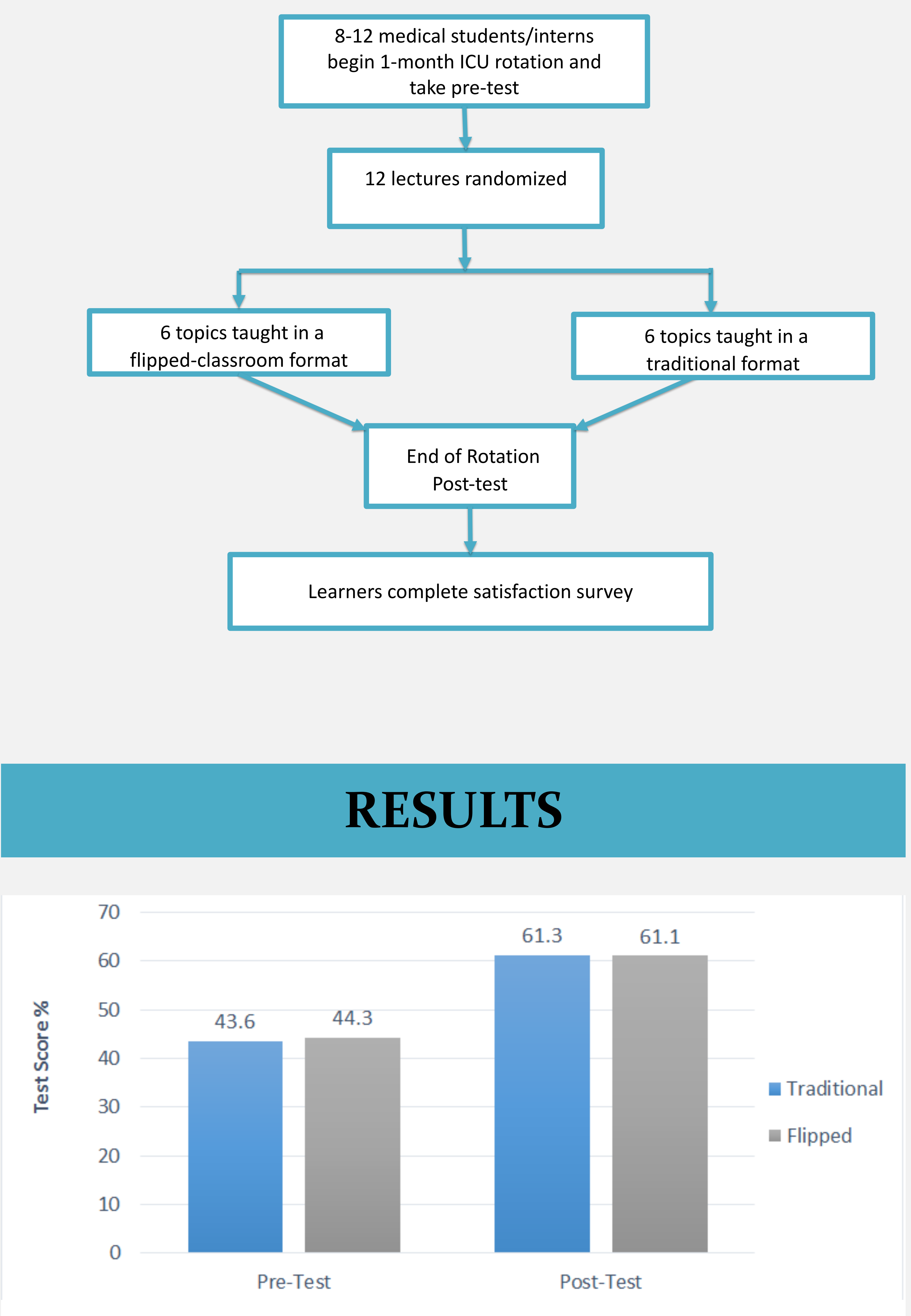

Figure 1. Increase in pre-test and post-test scores was not significantly different between the

\section{RESULTS}

Fifty-nine interns and medical students participated in the study. This group was comprised of 36 interns and 23 medical students. Fifty-four of these participants completed both pre- and post-tests. For the pretest, participants answered $44.3 \%$ (s.d. 14.7) correctly on the "flipped" questions and $43.6 \%$ (s.d. 14.2) on the "traditional" questions. There was no significant difference (as expected) between the groups on the pre-test. For the post-test, the participants exposed to "Flipped" teaching content answered $61.1 \%$ (s.d. 19.9) of questions correctly, which was a significant improvement from the pre-test $(P<0.001)$. Similarly, when learners were exposed to "traditional" learning content, their performance on questions increased to $61.3 \%$ (s.d. 16.6). This increase was also statistically significant $(p<0.001)$. While both teaching activities significantly improved their test performance, there was no significant difference in the amount of improvement between "flipped" vs "traditional" teaching

30 participants completed the survey at the end of their rotation. Fifteen (50\%) preferred the flipped classroom format as compared to $7(23 \%)$ that preferred the traditional format $(p=.03)$.

\section{DISCUSSION}

The flipped classroom format is being increasingly used in higher medical education. We assessed the utilization of a flipped classroom in a one-month critical care curriculum for medical students and interns by comparing it to a traditional lecture-based format. Our study showed there was no difference between the flipped and traditional formats in increasing knowledge of critical care topics among learners. However, a majority of learners preferred the flipped format over the traditional format. The flipped format also allowed for learning of these fundamental concepts on their own time and at their own pace. Furthermore, a shorter duration for the in-class sessions freed up both teachers and students to focus on other patient-care related activities in a busy intensive care unit. A flipped classroom format is not inferior to a traditional format in delivering a critical care curriculum to medical students and interns. 